\title{
PERBANDINGAN TINGKAT KESEHATAN BANK UMUM KONVENSIONAL DAN BANK UMUM SYARIAH MENGGUNAKAN METODE RGEC (RISK PROFILE, GOOD CORPORATE GOVERNANCE, EARNINGS, DAN CAPITAL)
}

\author{
Zara Zettyra R.D*1, Evi Mutia ${ }^{* 2}$ \\ ${ }^{1,2}$ Program Studi Akuntansi Fakultas Ekonomi dan Bisnis Universitas Syiah Kuala \\ e-mail: 2rdzarazettyra@ gmail.com $^{* 1}$, evimutiafe@ unsyiah.ac.id ${ }^{* 2}$
}

\begin{abstract}
The purpose of this study was to see a comparison of the health levels of conventional commercial banks and Islamic commercial banks using the RGEC method in the 2014-2017 period. The sample of this study were 30 conventional commercial banks and 11 sharia commercial banks. The assessment used uses the RGEC method (Risk Profile, Good Corporate Governance, Earnings, Capital) Risk Profile seen through the NPL and NPF indicators for conventional commercial banks while Islamic banks use LDR and FDR. Corporate governance is measured through Self Assessment. Earnings are measured through ROA and NIM indicators. Capital is measured based on the CAR indicator. Testing the hypothesis in this study using the Independent T-Test and Mann-Wnithey Test samples. The results of this study indicate that there is a difference between conventional commercial banks and Islamic commercial banks seen from the ratio of NPL, LDR, and ROA. While the ratio of GCG, NIM, and CAR does not have a significant difference between conventional commercial banks and Islamic commercial banks.
\end{abstract}

Keywords: Comparison of the health, RGEC, Independen T-Test, dan Mann-Wnithey Test.

\section{Pendahuluan}

Perkembangan zaman membentuk adanya terobosan-terobosan baru yang semakin meningkat, terutama di sektor keuangan dan perekonomian. Peran sektor keuangan dan perkonomian sangat penting, apabila berkaitan dengan adanya penyediaan dana untuk pembiayaan ekonomi (investasi). Dana tersebut biasanya disediakan oleh pihak perbankan. Perbankan adalah salah satu bidang keuangan yang diharapkan mampu memainkan peran aktif Nasional dalam perkembangan pertumbuhan ekonomi saat ini (Muctar Bustari et al, 2016). Pertumbuhan ekonomi adalah peningkatan hasil masyarakat yang menyebabkan semakin banyaknya jumlah faktor produksi yang digunakan dalam mengukur keberhasilan pembangunan suatu negara (Sattar, 2017).

Salah satu unsur yang sangat diperhatikan dalam perbankan adalah kesehatan perbankannya. Bank yang dinyatakan sehat adalah bank yang mampu melakukan kegiatan operasional perbankan secara terkendali dan mampu memenuhi semua kewajibannya dengan baik, yang sesuai dengan peraturan yang telah diterapkan (Musctar Bustari et al, 2016). Aspek yang penting untuk mengetahui kesehatan bank adalah dengan melakukan penilaian dimana penilaian tersebut perlu diketahui oleh stakeholders (pemangku kepentingan). Penting untuk melakukan penilaian kesehatan perbankan yang menerapkan GCG (Good Corporate Governance) secara baik untuk menghadapi risiko yang akan datang dimasa depan, penilaian ini memudahkan pihak stakeholder dalam mengambil keputusan untuk kepentingan perusahaan (PBI No.13/1/PBI/2011).

Penilaian yang pertama kali digunakan dalam menilai kesehatan perbankan adalah CAMEL. CAMEL adalah metode kesehatan bank yang menilai besarnya rasio- rasio modal (capital), aktiva (assets), manajemen (management), rentabilitas (earnings), dan likuiditas (liquidity) (PBI No.6/23/DPNP/2004). Namun Bank Indonesia telah melakukan pembaruan dalam menilai kesehatan perbankan. Penilaian kesehatan perbankan kini berevaluasi menjadi RGEC (Risk Profile, Good Corporate Governance, Earnings, Capital). Perubahan ini tercantum pada surat edaran Bank Indonesia No. 13/24/DPNP Tanggal 25 Oktober 2011 tentang menilai kesehatan bank dan berlaku sejak 1 Januari 2012. Menurut peraturan yang telah dikeluaran Bank Indonesia No. 13/1/PBI/2011 Pasal 7 penilaian kesehatan perbankan harus dinilai berdasarkan komponen yang ada dalam RGEC (Risk 
Profile, Good Corporate Governance, Earnings, Capital).

Penilaian menggunakan RGEC (Risk Profile, Good Corporate Governance, Earnings, Capital) dimulai dari menilai Risk Profile perbankan. Penilaian risk profile adalah menilai risiko inheren dan risiko kualitas dalam setiap aktivitas operasional bank. Selanjutnya, GCG (Good Corporate Governance) penilaian ini berfokus terhadap kualitas manajemen bank yang mendasarkan kepada 5 prinsip GCG. Earnings atau penilaian faktor rentabilitas yang terdiri dari evaluasi kinerja rentabilitas, sumber-sumber rentabilitas, kesinambungan rentabilitas, dan manajemen rentabilitas. Penilaian yang terakhir adalah capital atau sering disebut permodalan. Penilaian ini terdari dari kecukupan modal dan bagaimana pengelolaan modal (PBI No.13/1/PBI/2011).

Penerapan RGEC (Risk Profile, Good Corporate Governance, Earnings, Capital) dalam perbankan konvensional dan syariah membuat adanya perubahan dalam hal manajemen. Perubahan yang terjadi mengakibatkan perubahan ekonomi masyarakat dan profil risiko bank yang semakin diperketat mengingat risiko kredit yang meningkat membuat pihak bank menerapkan manajemen risiko dan Good Corporate Governance. Tujuannya adalah agar setiap bank mampu menganalisis permasalahan secara lebih cepat dan melakukan tindakan pencegahan atau memperbaiki masalah lebih cepat dan tepat (Khalil \& Fuadi 2016).

Bank Umum Konvensional dan Bank Umum Syariah melakukan penilaian kesehatan perbankan setiap periode. Informasi yang didapat dari setiap periode penilaian akan membantu Bank Indonesia dalam membuat strategi baru bagi perbankan dan melakukan pengawasan yang lebih efisien. Kesehatan bank harus dijaga dan ditingkatkan agar kepercayaan masyarakat terhadap pihak perbankan tetap terjaga (Otoritas Jasa Keuangan, 2014). Peraturan OJK No.8 tahun 2014 pasal 9 menyebutkan kondisi bank yang sehat dinilai mampu menghadapi pengaruh negatif yang signifikan dari adanya perubahan kondisi bank yang tercermin dari peringkat faktor-faktor penilaian kesehatan perbankan yang berupa faktor profil risiko, penerapan Goog Corporate Governance, rentabilitas dan permodalan yang secara umum dikatakan dalam kondisi yang sehat.
Saat ini, pihak OJK melepaskan pengawasannya terhadap Bank Banten karena bank tersebut dinilai tidak memiliki masalah lagi dengan kesehatan perbankannya. Rasio kecukupan modal (CAR) milik Bank Banten sudah di atas profil risiko setelah ditambah modal dari pemilik baru, yakni Pemprov Banten. Pada Februari 2017, bank Banten menyalurkan kredit sebesar Rp 3,32 triliun, atau tumbuh $3,1 \%$ ketimbang penyaluran kredit pada Januari 2017 yang sebesar Rp 3,2 triliun. Dana pihak ketiga, angkanya tercatat $\mathrm{Rp} 5.3$ triliun, meningkat dari bulan sebelumnya. Kondisi ini menunjukkan kesehatan bank yang membaik, seiring dengan membaiknya penyaluran dana atau kredit di dalamnya (www.mediaindonesia.com, diakses 16 Maret 2017).

Selanjutnya, Bank Muamalat Indonesia Tbk bersikeras bahwa kondisi perusahannya dalam keadaan baik-baik saja, meskipun rasio pembiayaan macet meningkat dan permodalannya dalam kondisi yang buruk. Direktur utama Bank Muamalat Achmad K Permana mengatakan bahwa perusahaan berada dalam kondisi baik. Kondisi likuiditas perusahaan yang menjadi parameter utama saat ini cukup baik, tercermin dalam rasio pendanaan pembiayaan FDR dikisaran 84\% (www.cnnindonesia.com, diakses 02 Maret 2018).

Dari fakta di atas dapat disimpulkan pentingnya dalam menilai kesehatan perbankan, karena dapat menilai secara keseluruhan apakah perusahaan tersebut dalam kondisi yang baik atau dalam kondisi yang krisis, sehingga pihak bank dapat membuat keputusan untuk memperbaiki kondisi bank yang buruk.

Dari fakta di atas dapat disimpulkan pentingnya dalam menilai kesehatan perbankan, karena dapat menilai secara keseluruhan apakah perusahaan tersebut dalam kondisi yang baik atau dalam kondisi yang krisis, sehingga pihak bank dapat membuat keputusan untuk memperbaiki kondisi bank yang buruk.

Penelitian sebelumnya pernah dilakukan oleh Fitriana et al (2015) dengan hasil penelitian tidak terdapat Non Performing Loans antara bank konvensional dan bank syariah. Hasil serupa juga ditunjukkan oleh Jayanti \& Isharijadi (2017). Berbeda dengan hasil penelitian yang dilakukan oleh Daniswara \& Sumarta (2016) bahwa terdapat perbedaan signifikasn pada Non Performing Loans antara bank umum konvensinal dan bank umum syariah. 
Lasta et al (2014) menunjukkan bahwa terdapat perbedaan Loan to Deposit Ratio antara bank konvensional dan bank syariah. Hasil tersebut sejalan dengan hasil penelitian (Danswara \& Sumarta, 2016). Hasil penelitian berbeda dilakukan Anggraini et al (2015) menurut Anggraini tidak terdapat perbedaan Loan to Deposit Ratio antara bank umum konvensional dan bank umum syariah.

Penelitian Fitriana et al (2015) menunjukkan bahwa adanya tidak ada perbedaan Good Corporate Governance antara bank umum syariah dan bank umum konvensional. Hasil tersebut berbeda dengan hasil penelitian yang dilakukan oleh sugari et al (2015) dimana sugari mendapatkan hasil bahwa terdapat perbedaan Good Corporate Governance antara bank umum konvensional dan bank umum syariah.

Hasil penelitian Deehani et al (2015) menunjukkan bahwa terdapat perbedaan pada Return on Assets antara bank syariah dan bank konvensional. Hasil serupa juga ditunjukkan oleh Daniswara \& Sumarta (2016). Berbeda dengan hasil penelitian yang dilakukan oleh Sugari et al (2015) bahwa tidak terdapat perbedaan kinerja keuangan yang dilihat dari Return on Assets antara bank syariah dan bank konvensional.

Hasil penelitia Sugari et al. (2015) bahwa terdapat perbedaan Capital Adequacy Ratio antara bank konvensional dan bank syariah. Hasil serupa ditunjukkan oleh Daniswara \& Sumarta (2016). Hasil berbeda ditunjukkan oleh Anggraini (2015) bahwa tidak terdapat perbedaan Capital Adequacy Ratio antara bank konvensional dan bank syariah.

Dari hasil kajian penelitian sebelumnya, masih ada peneliti yang tidak membandingkan kinerja bank umum konvensional dengan bank umum syariah khususnya pada bank umum yang membuka layanan konvensional sekaligus syariah. berdasarkan alasan inilah maka peneliti merasa tertarik untuk meneliti perbandingan tingkat kesehatan bank umum konvensional dan bank umum syariah menggunakan instrument terbaru dari Bank Indonesia yaitu RGEC.

\section{Kerangka Teoritis Dan Pengembangan Hipotesis \\ Kajian Pustaka \\ Kesehatan Bank}

Perkembangan dalam industri perbankan terutama dalam produk dan jasa sangat meningkatkan risiko dan profil bank. Peningkatan tersebut menerapkan adanya pendekatan dan pengawasan risiko yang mepengaruhi penilaian tingkat kesehatan perbankan. Kesehatan bank adalah kondisi keuangan dan manajemen bank yang diukur melalui rasio-rasio dan mendapatkan penilaian sehat atau tidaknya suatu bank (Muctar Bustari et al, 2016). Kesehatan bank menjadi bagian penting bagi pihak yang memerlukannya, yaitu stakeholders, masyarakat pengguna jasa bank, dan Bank Indonesia selaku pengawas dan Pembina bank yang ada di Indonesia (Sunarti, 2011).

Bank yang sehat adalah bank yang dapat menjaga dan memelihara kepercayaan masyarakat, dapat menjalankan fungsi intermediasi, dapat membantu kelancaran lalu lintas pembayaran serta dapat digunakan oleh pemerintah dalam menjalankan tugasnya (Khalil \& Fuadi, 2016). Fungsi-fungsi tersebut dijalankan dapat memberikan pelayanan yang baik kepada masyarakat serta bermanfaat bagi perekonomian secara keseluruhan. Sesuai dengan Peraturan Otoritas Jasa Keuangan No.4/POJK.03/2016 bahwa bank wajib memelihara dan meningkatkan Tingkat Kesehatan Bank dengan menerapkan prinsip kehati-hatian dan manajemen risiko dalam melaksanakan kegiatan usaha.

Perkembangan sektor bank yang memetingkan kesehatan bank dalam meningkatkan potensi bank dan menghindari terjadinya krisis membuat perbankan menjadi berkembang pesat (Sugari et al, 2015). Sektor perbankan menjadi panutan yang lebih dominan dalam sistem keuangan. Oleh sebab, itu apabila terjadi kegagalan dalam sektor perbankan yang menimbulkan dampak ketidakstabilan keuangan dan dapat mengganggu meningkatnya perekonomian (www.bi.go.id, diakses pada 20 November 2014). Kinerja bank yang buruk dapat membuat bank lain ikut terinfeksi dan mengakibatkan ketidakstabilan keuangan dan berujung pada kegagalan sistem perekonomian. Karenanya, dengan adanya kesehatan perbankan dapat memprediksi adanya kegagalan finansial yang terjadi sehingga mampu mencegah atau mengurangi efek negatif yang dapat mepengaruhi keseimbangan sistem perekonomian (Boyacioglu, et al(2008) dalam Sugari et al., 2015).

Pihak bank Indonesia berusaha dalam menjaga otoritas moneter perbankan, sistem pembayaran dan menjaga kestabilitasan sistem keuangan negara. Bank 
Indonesia telah beberapa kali melakukan perubahan dalam menilai metode kesehatan bank. Metode CAMEL pertama kali diperkenalkan di Indonesia pada bulan Februari 1991 untuk mengukur tingkat kesehatan perbankan. Dalam metode CAMEL unsurunsur yang dinilai untuk melihat tingkat kesehatan bank antara lain: Capital, Asset Quality, Management, Earnings, dan Liquidity yang kemudian metode ini berubah menjadi CAMELS. Dalam metode CAMELS unsur-unsur yang dinilai untuk melihat tingkat kesehatan bank antara lain: Capital, Asset Quality, Management, Earnings, Liquidity dan Sensitivity to Market Risk (PBI No.6/23/DPNP/2004).

Saat ini Bank Indonesia telah mengeluarkan PBI No.13/1/PBI/2011 dan SE BI No.13/24/DPNP yang berlaku per Januari 2012 menggantikan cara lama penilaian kesehatan bank dengan metode CAMELS dengan metode RGEC. Metode CAMELS tersebut sudah diberlakukan selama hampir delapan tahun sejak terbitnya PBI No.6/10/PBI/2004 dan SE.No.6/23/DPNP. Dengan terbitnya PBI dan SE terbaru, metode CAMELS dinyatakan tidak berlaku lagi, diganti dengan model baru yang mewajibkan perbankan untuk melakukan penilaian sendiri (selfassessment) tingkat kesehatan bank dengan menggunakan metode RGEC baik secara individual maupun secara konsolidasi (www.ojk.go.id, diakses pada 12 Desember 2017). Dalam metode RGEC unsur-unsur yang dinilai untuk melihat tingkat kesehatan bank antara lain: Risk Profile, Good Corporate Governance, Earnings dan Capital.

\section{Metode RGEC}

Metode RGEC (Risk Profile, Good Corporate Governance, Earnings dan Capital) merupakan metode baru yang dikeluarkan oleh pihak Bank Indonesia dalam Surat Edaran Bank Indonesia No.13/24/DNPN pada tahun 2011 berisi tentang penilaian tingkat kesehatan bank dalam mengukur pendekatan risiko dan menghasilkan tingkat kesehatan bank yang baik.

\section{Penilaian Profil Risiko}

Penilaian profil risiko merupakan penilaian terhadap risiko inheren, kualitas penerapan manajemen risiko, dan tingkat risiko dalam operasional bank. Peraturan Bank Indonesia No.13/1/PBI/2011 yang menjelaskan tentang sistem penilaian profil risiko inheren dan kualitas penerapan manajemen risiko dalam operasional bank yang dilakukan terhadap 8 (delapan) risiko yaitu:

1) Risiko Kredit

Risiko kredit adalah risiko yang terjadi kegagalan apabila debitur atau pihak lain dalam memenuhi kewajiban kepada pihak bank seperti pinjaman yang tidak kembali sesuai dengan perjanjian, penundaan pembayaran jaminan, pengurangan pembayaran pokok pinjaman, atau sama sekali tidak membayar. Risiko ini sangat membantu dalam melihat aktivitas bank (Gustina, 2015). Rasio yang digunakan dalam mengukur risiko kredit adalah NPL (Non Performing Loan). NPL digunakan untuk menunjukkan kemampuan dari pihak manajemen bank dalam mengelola kredit bermasalah dari total kredit yang diberikan pihak bank yang memiliki problem dalam pengembalian kredit tersebut.

2) Risiko Pasar

Risiko pasar biasanya timbul dikarenakan menurunnya nilai dari suatu investasi karena adanya pergerakan dari faktor-faktor pasar. Risiko pasar terjadi karena adanya pengaruh antara gejolak suku bunga, perubahan nilai saham, nilai tukar, dan perubahan komoditas. Rasio yang digunakan untuk risiko pasar ini adalah IRR (Interest Rate Risk). Rasio ini digunakan untuk mengetahui tingkat suku bunga, nilai tukar yang beredar dan untuk mengukur sensitivitas dan liabilitas terhadap suku bunga.

3) Risiko Likuiditas

Risiko ini biasanya disebabkan Karena pihak bank tidak mampu memenuhi kewajiban yang telah jatuh tempo. Ketidakmampuan dari pihak bank ini disebabkan ketidakmampuan offsetting posisi tertentu dengan pasar disebabkan karena kondisi likuiditas pasar yang tidak memadai, ketidakmampuan mencairkan asset likuidnya untuk mengubah menjadi dana yang likuid, ketidakmampuan pihak bank dalam mencari pinjaman dan membiayai likuiditas.

4) Risiko Operasional

Risiko operasional adalah risiko yang terjadi akibat kurang optimalnya fungsi dari sistem informasi dan pengawasan bank. Risiko ini mengakibatkan kerugian dan kegagalan yang disebabkan tidak memadainya proses internal, kesalahan manusia, 
kegagalan sistem, atau adanya masalah internal yang mepengaruhi operasional bank (Yusmad Muammar Arafat, 2018:102).

5) Risiko Hukum

Risiko hukum adalah risiko yang berpotensi mengakibatkan kerugian karena kelemahan dari aspek yuridis, baik dalam bentuk tuntutan hukum, tidak adanya peraturan undang-undang yang mendukung adanya aktivitas.

6) Risiko Stratejik

Risiko stratejik terjadi akibat adanya penetapan dan pelaksanaan strategi bank yang tidak mampu bersifat responsive terhadap perubahan eksternal bank.

7) Risiko Kepatuhan

Risiko yang terjadi apabila tidak patuh dalam melaksanakan peraturan perundangan dan ketentuan yang berlaku adalah timbulnya kerugian baik secara langsung maupun tidak langsung.

8) Risiko Reputasi

Merupakan risiko yang disebabkan adanya publikasi negatif yang mulai terkait dengan kegiatan usaha bank atau persepsi negatif terhadap bank yang mengakibatkan menurunnya tingkat kepercayaan stakeholder.

Dalam delapan risiko tersebut, peneliti hanya menggunakan risiko kredit dan risiko likuiditas dalam penelitian ini. Kedua risiko tersebut digunakan karena peneliti dapat memperoleh data kuantitatif dan memiliki kriteria yang cocok dalam menilai kesehatan perbankan. Sedangkan hal tersebut tidak dapat diperoleh pada risiko pasar, risiko operasional, risiko hukum, risiko stratejik, risiko kepatuhan, dan risiko kepatuhan (Prastyananta et al 2016).

\section{Penilaian GCG (Good Corporate Governance)}

GCG (Good Corporate Governance) menurut PBI No.8/4/PBI/2006 adalah penilaian tata kelola bank yang menerapkan dan melaksanakan prinsip-prinsip GCG. Prinsip tersebut berisi ketentuan yang menerapkan prinsip keterbukaan (transparency), akuntabilitas (accountability), pertanggungjawaban (responsibility), independensi (independensy), dan kewajaran (fainess). Ketentuan yang berlaku, setiap bank wajib melakukan penilaian mandiri (self assessment) dan pelaksanaan GCG, serta menyusun laporan pelaksanaan GCG secara berkala (PBI No.15/15/DPNP/2013). FCGI (Forum for corporate governance) mempublikasikan menggunakan definisi Cadbury committee "Suatu ketentuan yang mengatur hubungan antara stakeholders, pengelola perusahaan, pihak kreditur, pemerintah, karyawan serta para pemegang kepentingan interen dan eksteren lainnya yang berkaitan dengan hak, kewajiban yang mengatur dan mengendalikan perusahaan" (Khalil \& Fuadi, 2016).

\section{Penilaian Rentabilitas (Earning)}

Rasio rentabilitas adalah rasio yang digunakan untuk menganalisis atau mengukur tingkat efisiensi usaha dan profitabilitas yang dicapai oleh bank dan Penilaian ini dilakukan setiap periode (Fitriana et al., 2015). Pada penilaian ini aspek yang yang akan dinilai adalah kemampuan bank dalam meningkatkan faktor rentabilitas meliputi evaluasi terhadap kinerja rentabilitas, sumber-sumber rentabilitas, dan sustainability rentabilitas bank dengan mempertimbangkan aspek tingkat, trend, struktur, dan stabilitas dengan meperhatikan kinerja pergroup serta manajemen rentabilitas bank.

Penetapan peringkat pada penilaian rentabilitas dilakukan berdasarkan analisis yang komprehensif terhadap indikator rentabilitas yang mepengaruhi rentabilitas bank. Rentabilitas yang meningkat menandakan bank menghasilkan yang efisien dan menunjukkan kondisi bank yang sehat. Penilaian terhadap faktor rentabilitas terhadap komponenkomponen: (Kasmir, 2007).

1) Pencapaian ROA (return on assets) dan NIM (net interest margin).

2) Perkembangan laba operasional, diversifikasi pendapatan, penerapan prinsip akuntansi dalam pengakuan pendapatan dan biaya, dan prospek laba operasional.

\section{Penilaian Permodalan (Capital)}

Penilaian faktor Permodalan meliputi evaluasi terhadap kecukupan permodalan dan kecukupan pengelolaan permodalan yang sesuai dengan kategori, skala usaha dan kompleksitas dari usaha bank (Putri \& Bambang, 2017). Dalam melakukan perhitungan Permodalan, Bank wajib mengacu pada ketentuan bank Indonesia yang mengatur mengenai kewajiban penyediaan modal minimum bagi bank umum. Selain itu, dalam melakukan penilaian kecukupan 
Permodalan, Bank juga harus mengaitkan kecukupan modal dengan Profil Risiko bank.

\section{Kerangka Pemikiran}

Melihat pada penelitian sebelumnya (Fitriana et al 2015) tingkat kesehatan Bank umum konvensional dan bank umum syariahmemiliki perbedaan yang signifikan, hal tersebut dikarenakan Bank Umum Konvensional memiliki peringkat profil risiko yang lebih rendah dibandingkan Bank Umum Syariah. Sedangkan pada penelitian (Jayanti \& Isharijadi 2017) menunjukkan hasil yang berbeda, dimana bank konvensional dan bank syariah memiliki tingkat risiko kredit yang sama. Hal tersebut ditunjukkan dengan tidak adanya perbedaan yang signifikan antara Non Performing Loan pada bank konvensional dan Non Performing Finance pada bank syariah.

penelitian (Fitriana et al 2015), tingkat kesehatan bank konvensional dan bank syariah memiliki perbedaan yang signifikan berdasarkan faktor Good Corporate Governance, dimana bank konvensional memiliki peringkat GCG yang lebih tinggi dibandingkan dengan bank syariah. Sedangkan pada penelitian (Sugari et al 2015) menunjukkan hasil yang berbeda, yaitu tingkat kesehatan bank konvensional dan bank syariah tidak memiliki perbedaan yang signifikan pada faktor GCG.

penelitian (Deehani et al, 2015), baik bank konvensional dan bank syariah memiliki kemampuan dalam menghasilkan laba yang hampir sama, dimana tidak ada perbedaan yang signifikan pada rasio profitabilitas antara bank konvensional dengan bank syariah. Hasil yang berbeda ditunjukkan pada penelitian (Sugari et al, 2015), yaitu bank konvensional memiliki kinerja yang lebih baik dibandingkan dengan bank syariah dilihat dari faktor earnings.

Pada penelitian (Sugari et al, 2015) menunjukkan bahwa bank konvensional dan bank syariah memiliki kinerja yang lebih baik dibandingkan dengan bank konvensional dilihat dari faktor capital. Sedangkan penelitian (Deehani et al, 2015) menunjukkan bahwa tidak ada perbedaan yang signifikan pada faktor capital antara bank konvensional dan bank syariah.

\section{Hipotesis}

Berdasarkan uraian dan kerangka pemikiran yang telah dijelaskan maka hipotesis penelitian antara lain adalah sebagai berikut:

H1: Ada perbedaan tingkat kesehatan bank umum konvensional dengan bank umum syariah jika dilihat dari rasio Non Performing Loan (NPL) periode 2014-2017

H2: Ada perbedaan tingkat kesehatan bank umum konvensional dengan bank umum syariah jika dilihat dari rasio Loan to Deposit Ratio (LDR) periode 2014-2017

H3: Ada perbedaan tingkat kesehatan bank umum konvensional dengan bank umum syariah jika dilihat dari rasio Good Corporate Governance periode 2014-2017

H4: Ada perbedaan tingkat kesehatan bank umum konvensional dengan bank umum syariah jika dilihat dari rasio Return on Assets (ROA) periode 2014-2017

H5: Ada perbedaan tingkat kesehatan bank umum konvensional dengan bank umum syariah jika dilihat dari rasio Net Interest Margin (NIM) periode 2014-2017

H6: Ada perbedaan tingkat kesehatan bank umum konvensional dengan bank umum syariah jika dilihat dari rasio Capital Adequacy Ratio (CAR) periode 2014-2017

\section{Metode Penelitian \\ Desain Penelitian}

Berdasarkan rumusan masalah yang diajukan peneliti. Penelitian ini dapat diklasifikasikan kedalam penelitian kuantitatif yang berbentuk komparatif. Menurut Sekaran \& Bougie (2017) penelitian kuantitatif yaitu data yang biasanya berbentuk angka atau data kualitatif yang diangkakan dan kemudian dianalisis statistik untuk mengolah datanya, Sedangkan penelitian komparatif adalah suatu penelitian yang bersifat membandingkan. Variabelnya masih sama dengan penelitian variabel mandiri, tetapi untuk sampel yang lebih dari satu atau dalam waktu yang berbeda. Dari penjelasan di atas penelitian ini mengacu pada pernyataan Siregar tersebut dengan berpedoman pada tema yang dipenuhi, tema yang dimaksud adalah:

1) Sifat Studi 
Sifat Studi dalam penelitian ini merupakan pengujian hipotesis. Penelitian ini juga termasuk penelitian yang bersifat komparatif yaitu penelitian yang bersifat membandingkan. Dalam penelitian ini membandingkan mana yang lebih sehat antara bank umum konvensional dan bank umum syariah menggunakan metode RGEC.

2) Jenis Penelitian

Penelitian ini merupakan jenis penelitian jenis deskriptif dan jenis kuantitatif sehingga dapat menggambarkan pembahasan yang lebih banyak yang dapat berhubungan dengan rumus bersumber dari laporan keuangan. Deskriptif kuantitatif menjelaskan tentang fakta-fakta dari objek yang diteliti dengan menganalisis data angka menggunakan metode statistik melalui pengujian hipotesis. Data yang digunakan adalah data sekunder. Sugiyono (2012:141) mendefinisikan sumber sekunder adalah sumber data yang diperoleh dengan cara membaca, mempelajari, dan memahami melalui media lain yang bersumber dari literatur, buku-buku, serta dokumen perusahaan.

3) Tingkat Intervensi Peneliti Terhadap Studi

Penelitian ini menggunakan tingkat intervensi minimal. Peneliti menyusun kerangka teoretis, mengumpulkan data relevan, dan menganalisisnya untuk mendapatkan temuan baru (Sekaran, 2013:99). Oleh karena itu tingkat intervensi peneliti rendah, dimana hanya mengumpulkan data berupa laporan keuangan tahunan yang selanjutnya dianalisis dengan menggunakan rasio keuangan.

4) Situasi studi

Situasi studi penelitian ini adalah situasi tidak diatur. Peneliti ingin mengetahui perbandingan kesehatan perbankan bank umum konvensional dan bank umum syariah menggunakan metode RGEC.

5) Unit Analisis

Unit analisis merupakan kesatuan data yang dikumpulkan selama tahap analisis data yang dikumpulkan selama tahap analisis data selanjutnya (Sekaran, 2013:104). Unit analisis yang digunakan dalam penelitian adalah bank umum konvensional dan bank umum syariah. Penentuan sampel yang menggunakan teknik purposive sampling, yaitu memilih data sesuai kriteria-kriteria tertentu dari peneliti.

\section{Populasi dan Sampel Penelitian}

Populasi dalam penelitian ini adalah semua bank umum konvensional dan bank umum syariah di Indonesia. Pada penelitian ini, sampel ditentukan dengan menggunakan metode purposive sampling. Purposive sampling adalah metode pemilihan sampel berdasarkan kriteria tertentu yang ditentukan oleh peneliti (Sekaran \& Bougie, 2017). Kriteria sampel tersebut adalah berikut:

1) Bank Umum Konvensional dan Bank Umum Syariah yang terdaftar di OJK

2) Bank Umum Konvensional dan Bank Umum Syariah yang menerbitkan laporan tahunan berturut pada tahun 2014-2017 dan mepublikasikannya melalui website masingmasing bank.

3) Bank Umum Konvensional dan Bank Umum Syariah yang menerbitkan laporan tahunan GCG secara berturut pada tahun 2014-2017 dan mepublikasikan melalui website masing-masing bank.

Adapun yang menjadi sampel dalam penelitian ini adalah sebagai berikut: Rincian sampel penelitian dapat dilihat pada tabel 3.1

Tabel 3.1

Populasi Penelitian

\begin{tabular}{|c|l|c|c|}
\hline No & Kriteria & Bank Umum Konvensional & Bank Umum Syariah \\
\hline 1 & $\begin{array}{l}\text { Bank umum konvensional dan bank umum syariah yang } \\
\text { terdaftar di OJK }\end{array}$ & 81 \\
\hline 2 & $\begin{array}{l}\text { Bank yang tidak menerbitkan laporan keuangan secara } \\
\text { berturut 2014-2017 }\end{array}$ & $(-)$ & $(1)$ \\
\hline 3 & $\begin{array}{l}\text { Bank yang tidak menerbitkan lapora GCG secara berturut } \\
\text { 2014-2017 }\end{array}$ & $(50)$ & 11 \\
\hline & Jumlah sampel penelitian & 30 & $\mathbf{4 1} \mathbf{~ 4 ~ t a h u n ~ = ~ 1 6 4 ~}$ \\
\hline \multicolumn{1}{|c|}{ Total }
\end{tabular}

Sumber: data diolah (2018) 


\section{Sumber dan Teknik Pengumpulan Data}

Data dalam penelitian ini menggunakan data sekunder. Sekaran (2013) data sekunder mengacu pada informasi yang dikumpulkan oleh seseorang dan bukan peneliti yang melakukan studi mutakhir. Data sekunder dimaksud dalam penelitian ini yaitu data informasi keuangan atau laporan keuangan tahunan bank umum konvensional dan bank umum syariah di Indonesia yang diperoleh dari situs resmi Bank Indonesia dan situs masing-masing bank umum syariah di Indonesia dalam periode 2014-2017. Penelitian ini merupakan jenis penelitian kuantitatif dimana jenis penelitian tersebut dibagi dalam jenis deskriptif dan jenis kuantitatif sehingga dapat menggambarkan pembahasan yang lebih banyak yang dapat berhubungan dengan rumus bersumber dari laporan keuangan.

Teknik pengumpulan data yang digunakan dalam penelitian ini adalah metode penelitian observasi, dokumentasi, dan penelusuran data online yang digunakan untuk mengevaluasi secara sistematis isi dari suatu informasi (Sekaran 2013). Metode observasi adalah metode pengumpulan data untuk menghimpun data penelitian. Metode dokumentasi adalah metode mengumpulkan data terkait dengan variabel penelitian. Metode penelusuran adalah cara mendapatkan data melalui fasilitas online yang berupa informasi teori ataupun data.

\section{Metode Analisis dan Rancangan Pengujian Hipotesis}

Metode Analisis

Metode analisis yang dilakukan untuk menguji hipotesis dalam penelitian ini untuk mengetahui tingkat kesehatan bank umum syariah dan bank umum konvensional, serta bertujuan untuk mengetahui apakah ada beda antara tingkat kesehatan bank umum konvensional dan bank umum syariah dengan metode RGEC. Untuk mengetahui tingkat kesehatan bank maka diperlukan sesuai dengan standarisasi pada metode RGEC. Dalam penelitian ini digunakan metode analisis deskriptif kuantitatif dengan mengolah laporan keuangan berdasarkan dengan rasio RGEC.

Jenis analisis statistic yang digunakan dalam penelitian ini ialah statistik inferensial. Statistik inferensial biasanya dipakai statistic parametric karena variabel- variabel dalam penelitian ini udah merupakan data kuantitatif sehingga tidak diperlukan penjabaran ke dalam dimensi lain. Selain itu teknik statistik ini menyediakan uji statistik untuk sampel kecil $(n<30)$ sehingga teknik statistik ini sesuai dengan penelitian penulis. Dengan menganlisis penelitian ini, peneliti menggunakan program computer SPSS 21.00 for windows.

\section{uji asumsi klasik}

Pengujian normalitas adalah pengujian tentang kenormalan distribusi data. Uji ini merupakan pengujian yang paling banyak dilakukan untuk analisis statistik parametrik. Karena data yang berdistribusi normal merupakan syarat dilakukannya tes parametrik. Sedangkan untuk data yang tidak mempunyai distribusi normal, maka analisisnya menggunakan tes non parametrik (Hafizah,2012). Pada penelitian ini uji normalitas dilakukan dengan metode uji kolmogorov-smirnov.

Sampel berdistribusi normal apabila Asymptotic sig > tingkat keyakinan yang digunakan dalam pengujian (tingkat kepercayaan $95 \%$ atau $\alpha=5 \%$ ). Sebaliknya sampel dikatakan tidak normal apabila asymptotic sig < tingkat kepercayaan. Jika sampel berdistribusi normal maka uji beda yang akan digunakan dalam penelitian ini adalah uji parametrik yaitu paired sample t-test dan jika sampel tidak berdistribusi normal maka uji beda yang akan digunakan adalah uji non parametrik yaitu wilcoxon sign test.

\section{Rancangan Pengujian Hipotesis}

Uji hipotesis yang dilakukan dalam penelitian ini adalah uji satistik non parametrik dan uji statistik parametrik. Uji statistik non parametrik digunakan apabila data kurang dari 30 , tidak berdistribusi normal dan tidak linear. Sementara Uji statistik parametrik digunakan apabila data berdistribusi normal.

Uji hipotesis pada penelitian ini menggunakan uji independent sample t-test dan mann-whitney test untuk melihat hubungan variabelvariabel yang diteliti. Analisis data ini dilakukan untuk melihat hubungan antar variabel apabila variabel lain konstan.

\section{Independent Sample T-Test}

Paired Sample T-Test adalah uji statistik parametrik yang digunakan untuk menguji hipotesis, 
jika data yang disajikan adalah data yang terdistribusi normal. Jika nilai prob $<$ nilai signifikansi $(\alpha=5 \%)$ maka dapat dikatakan hipotesis diterima, atau dengan kata lain terdapat perbedaan yang signifikan antara sebelum dan setelah menerbitkan obligasi syariah.

\section{Uji Mann Whitney Test}

Digunakan untuk menguji hipotesis jika data terdistribusi tidak normal, dengan menggunakan tingkat signifikasi $\alpha=5 \%$. Sehingga, jika prob $<$ taraf signifikasi maka variabel independen tersebut berpengaruh terhadap variabel dependen, berarti terdapat perbedaan yang secara statistik signifikan masing-masing rasio keuangan antara sebelum dan setelah menerbitkan obligasi syariah atau dengan kata lain hipotesis diterima.

Hipotesis diterima ataupun ditolak apabila:

1. Jika stastistik dengan nilai signifikasi $>5 \%$ maka H0 diterima (Ha ditolak), artinya tidak terdapat perbedaan secara signifikan.

2. Jika stastistik dengan nilai signifikasi $<5 \%$ maka H0 ditolak (Ha diterima), artinya terdapat perbedaan secara signifikan.

\section{Hasil Dan Pembahasan}

Statistik Deskriptif

Statistik Deskriptif Bank Umum Konvensioanal

Tabel 4.1

Statistik Deskriptif Bank Umum Konvensional

\begin{tabular}{|l|r|r|r|r|r|}
\hline & \multicolumn{1}{|c|}{ Descriptive Statistics } \\
\hline & $\mathrm{N}$ & Minimum & Maximum & \multicolumn{1}{c|}{ Mean } & $\begin{array}{c}\text { Std. } \\
\text { Deviation }\end{array}$ \\
\hline CAR Konvensional & 30 & 12.72 & 32.08 & 20.1527 & 4.69192 \\
GCG Konvensional & 30 & 1.00 & 3.00 & 1.9417 & .44858 \\
LDR Konvensional & 30 & 50.90 & 104.99 & 83.2167 & 11.56646 \\
NIM Konvensional & 30 & 1.91 & 8.21 & 4.8553 & 1.50933 \\
NPL Konvensional & 30 & .02 & 7.69 & 2.7283 & 1.43513 \\
ROA Konvensional & 30 & -2.99 & 4.11 & 1.1107 & 1.65048 \\
Valid N (listwise) & 30 & & & & \\
\hline
\end{tabular}

Sumber: Hasil Output SPSS (2018)

Hasil perhitungan secara statistika dapat dilihat bahwa apabila nilai mean lebih besar dari standar deviasi maka dapat disimpulkan bahwa dari enam variabel yang memiliki varians kecil, sedangkan pada penelitian ini menghasilkan standar deviasi yang kecil pada bank umum konvensional itu berarti bank umum konvensional memiliki nilai mean lebih tinggi dibandingkan standar deviasi. Data tersebut dapat dilihat pada rasio CAR, GCG, NIM, NPL, LDR, dan
ROA. Berdasarkan output tampilan SPSS diatas menunjukkan bahwa jumlah sampel (N) berjumlah 30 .

1. Rasio Capital Adequacy Ratio (CAR) terkecil adalah 12, 72 dan rasio tertinggi adalah 32,08 . Rata-rata rasio CAR dari 30 data adalah 20, 1527 dengan standar deviasi sebesar 4, 69192. Nilai rata-rata lebih besar daripada nilai standar deviasi menunjukkan rendahnya variansi sehingga disimpulkan bahwa data tersebut mengalami penyimpangan yang kecil.

2. Rasio Good Corporate Governance (GCG) terkecil adalah 1, 00 dan rasio tertinggi adalah 3, 00. Rata-rata rasio GCG dari 30 data adalah 1, 9417 dengan standar deviasi sebesar 0, 44858. Nilai rata-rata lebih besar daripada nilai standar deviasi menunjukkan rendahnya variansi sehingga disimpulkan bahwa data tersebut mengalami penyimpangan yang kecil.

3. Rasio Loan to Deposit Ratio (LDR) terkecil adalah 50, 90 dan rasio tertinggi adalah 104, 99. Rata-rata rasio LDR dari 30 data adalah 83, 2167 dengan standar deviasi sebesar 11, 56646. Nilai rata-rata lebih besar daripada nilai standar deviasi menunjukkan rendahnya variansi sehingga disimpulkan bahwa data tersebut mengalami penyimpangan yang kecil.

4. Rasio Net Interest Margin (NIM) terkecil adalah 1, 91 dan rasio tertinggi adalah 8,21 . Rata-rata rasio NIM dari 30 data adalah 4, 8553 dengan standar deviasi sebesar 1, 50933. Nilai rata-rata lebih besar daripada nilai standar deviasi menunjukkan rendahnya variansi sehingga disimpulkan bahwa data tersebut mengalami penyimpangan yang kecil.

5. Rasio Non Performing Loan (NPL) terkecil adalah 0,02 dan rasio tertinggi adalah 7, 69. Ratarata rasio NPL dari 30 data adalah 2, 7283 dengan standar deviasi sebesar 1, 43513. Nilai rata-rata lebih besar daripada nilai standar deviasi menunjukkan rendahnya variansi sehingga disimpulkan bahwa data tersebut mengalami penyimpangan yang kecil.

6. Rasio Return on Assets (ROA) terkecil adalah -2, 99 dan rasio tertinggi adalah 4, 11. Rata-rata rasio ROA dari 30 data adalah 1, 1107 dengan standar deviasi sebesar 1, 65048. Nilai rata-rata lebih besar daripada nilai standar deviasi menunjukkan rendahnya variansi sehingga disimpulkan bahwa 
data tersebut mengalami penyimpangan yang kecil.

\section{Statistik Deskriptif Bank Umum Syariah}

Pada Tabel 4.2 menunjukkan variabel Bank umum syariah yang dilihat dari nilai minimum, nilai maksimum, mean, dan standar deviasi.

Tabel 4.2

Statistik Deskriptif Bank umum syariah

\begin{tabular}{|l|r|r|r|r|r|}
\multicolumn{7}{c|}{ Descriptive Statistics } \\
\hline & N & Minimum & Maximum & \multicolumn{1}{c|}{ Mean } & $\begin{array}{c}\text { Std. } \\
\text { Deviation }\end{array}$ \\
\hline CAR Syariah & 11 & 13.16 & 55.61 & 21.8700 & 12.30138 \\
GCG Syariah & 11 & 1.00 & 3.00 & 2.0227 & .54146 \\
LDR Syariah & 11 & 80.19 & 122.25 & 92.5791 & 11.03122 \\
NIM Syariah & 11 & 2.91 & 8.21 & 5.2909 & 1.96285 \\
NPL Syariah & 11 & .41 & 13.20 & 5.1373 & 3.24233 \\
ROA Syariah & 11 & -5.14 & 1.36 & -.5873 & 2.08728 \\
Valid N (listwise) & 11 & & & & \\
\hline
\end{tabular}

Sumber: Hasil Output SPSS (2018)

Hasil perhitungan secara statistika dapat dilihat bahwa apabila nilai mean lebih besar dari standar deviasi maka dapat disimpulkan bahwa dari enam variabel yang memiliki varians kecil, sedangkan pada penelitian ini menghasilkan standar deviasi yang kecil pada bank umum syariah itu berarti bank umum syariah memiliki nilai mean lebih tinggi dibandingkan standar deviasi. Data tersebut dapat dilihat pada rasio CAR, GCG, NIM, NPL, dan LDR. Sedangkan untuk rasio ROA memiliki nilai rata-rata lebih kecil dibandingkan dengan standar deviasi hal ini menunjukkan varians yang besar. Berdasarkan output tampilan SPSS diatas menunjukkan bahwa jumlah sampel (N) berjumlah 11.

1. Rasio Capital Adequacy Ratio (CAR) terkecil adalah 13, 16 dan rasio tertinggi adalah 55, 61. Rata-rata rasio CAR dari 11 data adalah 21, 8700 dengan standar deviasi sebesar 12, 30138. Nilai rata-rata lebih besar daripada nilai standar deviasi menunjukkan rendahnya variansi sehingga disimpulkan bahwa data tersebut mengalami penyimpangan yang kecil.

2. Rasio Good Corporate Governance (GCG) terkecil adalah 1, 00 dan rasio tertinggi adalah 3, 00. Rata-rata rasio GCG dari 11 data adalah 2, 0227 dengan standar deviasi sebesar 0, 54146. Nilai rata-rata lebih besar daripada nilai standar deviasi menunjukkan rendahnya variansi sehingga disimpulkan bahwa data tersebut mengalami penyimpangan yang kecil.

3. Rasio Loan to Deposit Ratio (LDR) terkecil adalah 80, 19 dan rasio tertinggi adalah 122, 25 . Rata-rata rasio LDR dari 11 data adalah 92, 5791 dengan standar deviasi sebesar 11, 03122. Nilai rata-rata lebih besar daripada nilai standar deviasi menunjukkan rendahnya variansi sehingga disimpulkan bahwa data tersebut mengalami penyimpangan yang kecil.

4. Rasio Net Interest Margin (NIM) terkecil adalah 2, 91 dan rasio tertinggi adalah 8,21 . Rata-rata rasio NIM dari 11 data adalah 5, 2909 dengan standar deviasi sebesar 1, 96285. Nilai rata-rata lebih kecil daripada nilai standar deviasi menunjukkan tingginya variansi sehingga disimpulkan bahwa data tersebut mengalami penyimpangan yang kecil.

5. Rasio Non Performing Loan (NPL) terkecil adalah 0, 41 dan rasio tertinggi adalah 13, 20. Rata-rata rasio NPL dari 11 data adalah 5, 1373 dengan standar deviasi sebesar 3, 24233. Nilai rata-rata lebih besar daripada nilai standar deviasi menunjukkan rendahnya variansi sehingga disimpulkan bahwa data tersebut mengalami penyimpangan yang kecil.

6. Rasio Return on Assets (ROA) terkecil adalah -5, 14 dan rasio tertinggi adalah 1,36 . Rata-rata rasio ROA dari 11 data adalah -0, 5873 dengan standar deviasi sebesar 2, 08728. Nilai rata-rata lebih kecil daripada nilai standar deviasi menunjukkan tingginya variansi sehingga disimpulkan bahwa data tersebut mengalami penyimpangan yang besar.

\section{Analisis Data}

Analisis data dalam penelitian ini dimulai dengan menguji normalitas data sampel perusahaan. Uji normalitas ini dilakukan untuk menentukan alat uji hipotesis yang akan digunakan untuk menguji sampel penelitian. Jika sampel penelitian terdistribusikan normal maka akan digunakan uji parametric yaitu dengan uji T-Test Independet, namun jika sampel penelitian tidak terdistribusikan normal, maka akan digunakan uji nonparametric yaitu dengan uji ManWhitney Test. Uji hipotesis dalam penelitian ini yaitu menguji perbandingan tingkat kesehatan Bank umum konvensional dan bank umum syariah menggunakan 
metode RGEC (Risk Profile, Good Corporate Governance, Earnings, Capital).

\section{Uji Normalitas Data}

Sebelum dilakukan uji beda terlebih dahulu dilakukan pengujian Kolmogorov-Smirnov test yang bertujuan mengetahui keselarasan data dengan

Tabel 4.3

Hasil Uji Kolmogorov-Smirnov

\begin{tabular}{|l|l|l|l|}
\hline \multicolumn{1}{|c|}{ Variabel } & \multicolumn{1}{c|}{ Bank } & \multicolumn{1}{c|}{ Sig Uji K-S } & \multicolumn{1}{c|}{ Ket } \\
\hline \multirow{2}{*}{ Capital Adequacy Ratio (CAR) } & BUK & 0,345 & Normal \\
\cline { 2 - 5 } & BUS & 0,131 & Normal \\
\hline \multirow{2}{*}{ Good Corporate Governance (GCG) } & BUK & 0,001 & Tidak Normal \\
\cline { 2 - 5 } & BUS & 0,529 & Normal \\
\hline \multirow{2}{*}{ Loan to Deposit Ratio (LDR) } & BUK & 0,602 & Normal \\
\cline { 2 - 5 } & BUS & 0,489 & Normal \\
\cline { 2 - 4 } & BUK & 0,960 & Normal \\
\cline { 2 - 4 } & BUS & 0,047 & Normal \\
\hline \multirow{2}{*}{ Non Performing Loan (NPL) } & BUK & 0,958 & Normal \\
\cline { 2 - 4 } & BUS & 0,464 & Normal \\
\hline Return on Assets (ROA) & BUK & 0,558 & Normal \\
\cline { 2 - 4 } & BUS & 0,355 & \\
\hline
\end{tabular}

Sumber : Data Diolah.

Berdasarkan kesimpulan yang dapat diambil dari hasil uji normalitas data dengan Kolmogorov Smirnov Test untuk keenam variabel diatas ada beberapa variabel yang tidak normal, atau tidak memenuhi persyaratan uji normalitas. Variabel yang normal seperti CAR, LDR, NIM, NPL, dan ROA akan menggunakan uji T-Test Independent sedangkan untuk variabel GCG yang berdistribusi tidak normal akan menggunakan uji Mann-Whitney Test.

\section{Uji Hipotesis}

\section{Uji T-Test Independent}

Setelah melakukan pengujian normalitas maka dilakukan uji independen untuk mengetahui perbandingan terhadap dua sampel yang tidak berhubungan apakah terdapat perbedaan atau tidak. Pengujian dilakukan untuk masing-masing variabel yang terdistribusi secara normal. Ada dua tahapan analisis yang harus dilakukan, yang pertama adalah menguji asumsi apakah varians populasi kedua sampel tersebut sama (Equal variance assumed) ataukah ternyata varians itu berbeda (Equal variance not assumed) dengan menilai nilai levene test. Setelah itu adalah melihat nilai t-test untuk menentukan apakah terdapat perbedaan nilai rata-rata secara signifikan. distribusi normal atau tidak. Jika nilai Asym Sig. (2tailed)> 0, 05 maka normalitas data terpenuhi, dan jika nilai Asymp Sig (2-tailed) < 0, 05 maka normalitas data tidak terpenuhi. Berikut ini merupakan tabel yang menunjukkan hasil uji normalias data uji KolmogorovSmirnov dapat dilihat pada tabel 4.3 
Tabel 4.4

Group Statistik NPL

Group Statistics

\begin{tabular}{|ll|r|r|r|c|}
\hline & Jenis Bank & \multicolumn{1}{|c|}{$\mathrm{N}$} & \multicolumn{1}{c|}{ Mean } & $\begin{array}{c}\text { Std. } \\
\text { Deviation }\end{array}$ & $\begin{array}{c}\text { Std. Error } \\
\text { Mean }\end{array}$ \\
\hline NPL & Syariah & 11 & 5.1373 & 3.24233 & .97760 \\
& Konvensional & 30 & 2.7283 & 1.43513 & .26202 \\
\hline
\end{tabular}

Sumber: Sumber: Hasil Output SPSS (2018)

Rata-rata bank umum konvensional adalah sebesar 2, 7283 sedangkan untuk rata-rata bank umum syariah sebesar 5, 1373. Dari pengujian secara matematis dapat dilihat dari jumlah rata-rata bahwa variabel NPL antara bank umum konvensional dan bank umum syariah memiliki rata-rata (Mean) berbeda. Dari tabel diatas dapat dilihat bahwa nilai NPL pada Bank umum syariah lebih besar dibandingkan dengan bank umum kovensional, hal ini dapat disimpulkan bahwa bank umum syariah lebih memiliki resiko yang lebih kecil. Dengan adanya perbedaan pengujian secara matematis maka diperlukan pengujian secara statistik. Perhitungan statistik sebagai berikut:

Tabel 4.5

Independent Sample Test NPL

Independent Samples Tes

\begin{tabular}{|c|c|c|c|c|c|c|c|c|c|}
\hline & \multicolumn{9}{|c|}{ NPL } \\
\hline & \multicolumn{2}{|c|}{$\begin{array}{l}\text { Levene's Test } \\
\text { for Equality of } \\
\text { Variances }\end{array}$} & \multicolumn{7}{|c|}{ t-test for Equality of Means } \\
\hline & \multirow[b]{2}{*}{$F$} & \multirow[b]{2}{*}{ Sig. } & \multirow[b]{2}{*}{$t$} & \multirow[b]{2}{*}{$d f$} & \multirow{2}{*}{$\begin{array}{l}\text { Sig. } \\
\text { (2-tale } \\
\text { d) }\end{array}$} & \multirow{2}{*}{$\begin{array}{c}\text { Mean } \\
\text { Differen } \\
\text { ce }\end{array}$} & \multirow{2}{*}{$\begin{array}{c}\text { Std. } \\
\text { Error } \\
\text { Differen } \\
\text { ce }\end{array}$} & \multicolumn{2}{|c|}{$\begin{array}{c}95 \% \text { Confidence } \\
\text { Interval of the } \\
\text { Difference } \\
\end{array}$} \\
\hline & & & & & & & & Lower & Upper \\
\hline $\begin{array}{l}\text { Equal variances } \\
\text { assumed }\end{array}$ & 4.273 & .045 & 3.324 & 39 & .002 & 2.40894 & .72469 & .94311 & 3.8748 \\
\hline $\begin{array}{l}\text { Equal variances } \\
\text { not assumed }\end{array}$ & & & 2.380 & 11.47 & .036 & 2.40894 & 1.01210 & .19235 & 4.6255 \\
\hline
\end{tabular}

Sumber: Hasil Output SPSS (2018)

Berdasarkan tabel dapat diuraikan hasil analisis pengujian hipotesa, terlihat uji homogen (F) untuk variabel NPL dengan Equal Variance Asuumed (diasumsikan kedua varians sama) adalah 4, 273 dengan probabilitas 0,045 . Oleh karena nilai probabilitas lebih besar dari 0, 05, maka Ho diterima atau dinyatakan bahwa kedua varians sama. Nilai $t$ hitung untuk variabel NPL dengan Equal Variance
Asuumed adalah 3, 324 dengan signifikansi 0,002, karena nilai signifikansi $0,002<0,05$, maka Ho ditolak dan Ha diterima, maka dapat dikatakan bahwa variabel NPL bank umum konvensional dan bank umum syariah mempunyai perbedaan yang signifikan.

\section{$\mathrm{H}_{2}$ : Ada perbedaan tingkat kesehatan bank umum konvensional dengan bank umum syariah jika dilihat dari faktor Loan to Deposit Ratio (LDR) 2014-2017. \\ Tabel 4.6 \\ Group Statistik LDR}

Group Statistics

\begin{tabular}{|ll|r|l|c|c|}
\hline & Jenis Bank & N & Mean & $\begin{array}{c}\text { Std. } \\
\text { Deviation }\end{array}$ & $\begin{array}{c}\text { Std. Error } \\
\text { Mean }\end{array}$ \\
\hline LDR & Syariah & 11 & 92.5791 & 11.03122 & 3.32604 \\
& Konvensional & 30 & 83.2167 & 11.56646 & 2.11174 \\
\hline
\end{tabular}

Sumber: Sumber: Hasil Output SPSS (2018)

Rata-rata bank umum konvensional adalah sebesar 83, 2167 sedangkan untuk rata-rata bank umum syariah sebesar 92, 5791. Dari pengujian secara matematis dapat dilihat dari jumlah rata-rata bahwa variabel LDR antara bank umum konvensional dan bank umum syariah memiliki rata-rata (Mean) berbeda. Dari tabel diatas dapat dilihat bahwa nilai LDR pada bank umum syariah lebih besar dibandingkan dengan bank umum kovensional, hal ini dapat disimpulkan bahwa bank umum syariah lebih memiliki resiko yang lebih kecil. Dengan adanya perbedaan pengujian secara matematis maka diperlukan pengujian secara statistik. Perhitungan statistik sebagai berikut:

Tabel 4.7

\section{Independent Sample Test LDR}

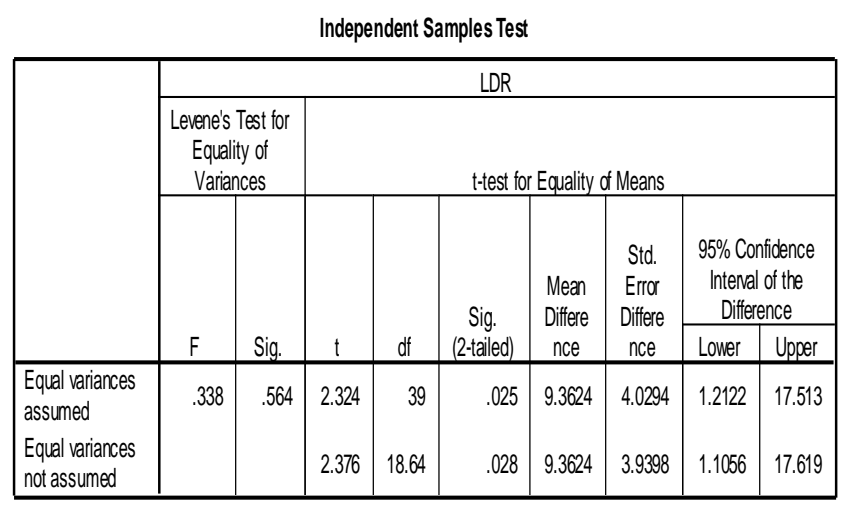

Sumber: Sumber: Hasil Output SPSS (2018) 
Berdasarkan tabel dapat diuraikan hasil analisis pengujian hipotesa, terlihat uji homogen (F) untuk variabel LDR dengan Equal Variance Asuumed (diasumsikan kedua varians sama) adalah 0,338 dengan probabilitas 0,564 . Oleh karena nilai probabilitas lebih besar dari 0,05 , maka Ho diterima atau dinyatakan bahwa kedua varians sama. Nilai $\mathrm{t}$ hitung untuk variabel LDR dengan Equal Variance Asuumed adalah 2, 324 dengan signifikansi 0, 025, karena nilai signifikansi $0,025<0,05$, maka Ho ditolak dan Ha diterima, maka dapat dikatakan bahwa variabel LDR bank umum konvensional dan bank umum syariah mempunyai perbedaan yang signifikan.

\subsubsection{Analisis Pengujian Hipotesis Earnings}

$\mathrm{H}_{3}$ : Ada perbedaan tingkat kesehatan bank umum konvensional dengan bank umum syariah jika dilihat dari faktor Net Interest Margin (NIM) 2014-2017.

Tabel 4.8

\section{Group Statistik NIM}

Group Statistics

\begin{tabular}{|ll|r|r|r|c|}
\hline & Jenis Bank & $\mathrm{N}$ & \multicolumn{1}{c|}{ Mean } & $\begin{array}{c}\text { Std. } \\
\text { Deviation }\end{array}$ & $\begin{array}{c}\text { Std. Error } \\
\text { Mean }\end{array}$ \\
\hline NIM & Syariah & 11 & 5.2909 & 1.96285 & .59182 \\
& Konvensional & 30 & 4.8553 & 1.50933 & .27556 \\
\hline
\end{tabular}

Sumber: Sumber: Hasil Output SPSS (2018)

Rata-rata bank umum konvensional adalah sebesar 4, 8553 sedangkan untuk rata-rata bank umum syariah 5, 2909. Dari pengujian secara matematis dapat dilihat dari jumlah rata-rata bahwa variabel NIM antara bank umum konvensional dan bank umum syariah memiliki rata-rata (Mean) berbeda. Dari tabel diatas dapat dilihat bahwa nilai NIM pada bank umum syariah lebih besar dibandingkan dengan bank umum kovensional, hal ini dapat disimpulkan bahwa bank umum syariah lebih memiliki tingkat efisiensi yang lebih baik. Dengan adanya perbedaan pengujian secara matematis maka diperlukan pengujian secara statistik. Perhitungan statistik sebagai berikut:
Tabel 4.9

\section{Independent Sample Test NIM}

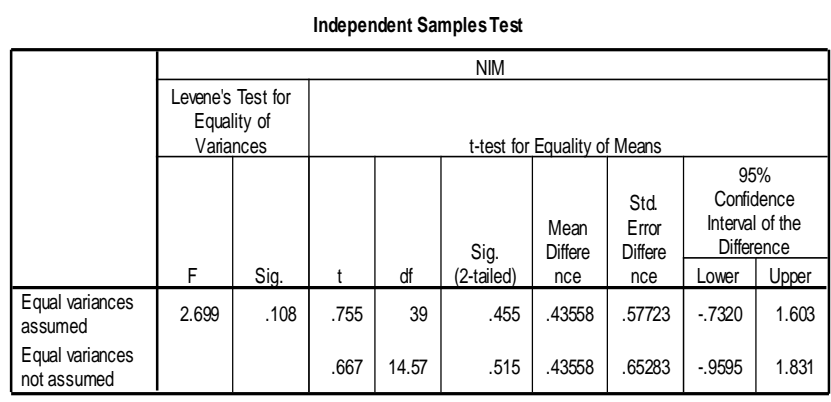

Sumber: Sumber: Hasil Output SPSS (2018)

Berdasarkan tabel dapat diuraikan hasil analisis pengujian hipotesa, terlihat uji homogen (F) untuk variabel NIM dengan Equal Variance Asuumed (diasumsikan kedua varians sama) adalah 2,699 dengan probabilitas 0,108 . Oleh karena nilai probabilitas lebih besar dari 0, 05, maka Ho diterima atau dinyatakan bahwa kedua varians sama. Nilai $\mathrm{t}$ hitung untuk variabel NIM dengan Equal Variance not Asuumed adalah 0, 667 dengan signifikansi 0, 515, karena nilai signifikansi $0,025>0,05$, maka Ho diterima dan Ha ditolak, maka dapat dikatakan bahwa variabel NIM bank umum konvensional dan bank umum syariah tidak mempunyai perbedaan yang signifikan.

\section{$\mathrm{H}_{4}$ : Ada perbedaan tingkat kesehatan bank umum konvensional dengan bank umum syariah jika dilihat dari faktor Return on Assets (ROA) 2014-2017.}

Tabel 4.10

Group Statistik ROA

Group Statistics

\begin{tabular}{|ll|r|r|r|c|}
\hline & Jenis Bank & $\mathrm{N}$ & \multicolumn{1}{c|}{ Mean } & $\begin{array}{c}\text { Std. } \\
\text { Deviation }\end{array}$ & $\begin{array}{c}\text { Std. Error } \\
\text { Mean }\end{array}$ \\
\hline ROA & Konvensional & 30 & 1.1107 & 1.65048 & .30134 \\
& Syariah & 11 & -.5873 & 2.08728 & .62934 \\
\hline
\end{tabular}

Sumber: Sumber: Hasil Output SPSS (2018)

Rata-rata bank umum konvensional adalah sebesar -0, 5873 sedangkan untuk rata-rata bank umum syariah 1, 1107. Dari pengujian secara matematis dapat dilihat dari jumlah rata-rata bahwa variabel ROA antara bank umum konvensional dan bank umum syariah memiliki rata-rata (Mean) berbeda. Dari tabel diatas dapat dilihat bahwa nilai 
ROA pada bank umum syariah lebih besar dibandingkan dengan bank umum kovensional, hal ini dapat disimpulkan bahwa bank umum syariah lebih memiliki kemampuan yang lebih tinngi dalam menghasilkan laba yang lebih baik. Dengan adanya perbedaan pengujian secara matematis maka diperlukan pengujian secara statistik. Perhitungan statistik sebagai berikut:

Tabel 4.11

Independent Sample Test ROA

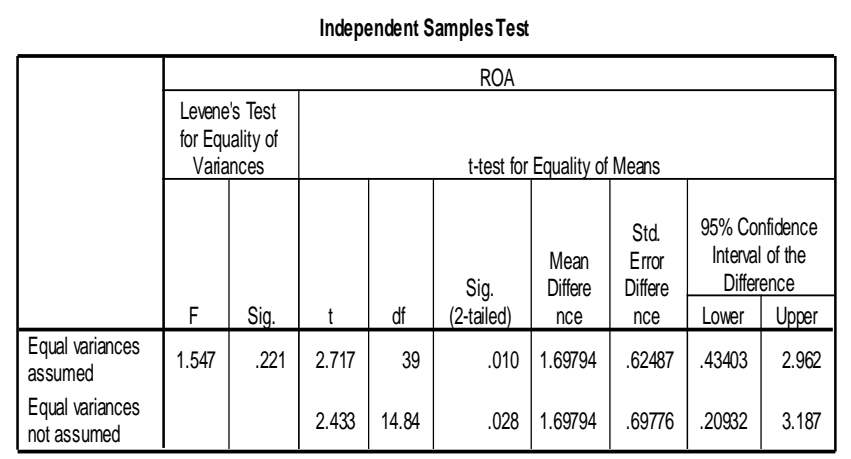

Sumber: Sumber: Hasil Output SPSS (2018)

Berdasarkan tabel dapat diuraikan hasil analisis pengujian hipotesa, terlihat uji homogen (F) untuk variabel ROA dengan Equal Variance Asuumed (diasumsikan kedua varians sama) adalah 1,547 dengan probabilitas 0,221. Oleh karena nilai probabilitas lebih besar dari 0, 05, maka Ho diterima atau dinyatakan bahwa kedua varians sama. Nilai $\mathrm{t}$ hitung untuk variabel ROA dengan Equal Variance Asuumed adalah 2,717 dengan signifikansi 0, 010, karena nilai signifikansi $0,010<0,05$, maka Ho ditolak dan Ha dititerima, maka dapat dikatakan bahwa variabel ROA bank umum konvensional dan bank umum syariah mempunyai perbedaan yang signifikan.

\section{Analisis Pengujian Hipotesis (Capital)}

$\mathrm{H}_{5}$ : Ada perbedaan tingkat kesehatan bank umum konvensional dengan bank umum syariah jika dilihat dari faktor Return on Assets (ROA) 2014-2017.
Tabel 4.12

Group Statistik CAR

Group Statistics

\begin{tabular}{|ll|r|r|r|r|}
\hline & Jenis Bank & $\mathrm{N}$ & Mean & $\begin{array}{c}\text { Std. } \\
\text { Deviation }\end{array}$ & $\begin{array}{c}\text { Std. Error } \\
\text { Mean }\end{array}$ \\
\hline CAR & Syariah & 11 & 21.8700 & 12.30138 & 3.70901 \\
& Konvensional & 30 & 20.1527 & 4.69192 & .85662 \\
\hline
\end{tabular}

Sumber: Sumber: Hasil Output SPSS (2018)

Rata-rata bank umum konvensional adalah sebesar 20, 1527 sedangkan untuk rata-rata bank umum syariah sebesar 21,8700. Dari pengujian secara matematis dapat dilihat dari jumlah rata-rata bahwa variabel CAR antara bank umum konvensional dan bank umum syariah memiliki rata-rata (Mean) berbeda. Dari tabel diatas dapat dilihat bahwa nilai CAR pada bank umum syariah lebih besar dibandingkan dengan bank umum kovensional, hal ini dapat disimpulkan bahwa bank umum syariah lebih memiliki kinerja yang lebih baik. Dengan adanya perbedaan pengujian secara matematis maka diperlukan pengujian secara statistik. Perhitungan statistik sebagai berikut:

Tabel 4.13

Independent Sample Test CAR

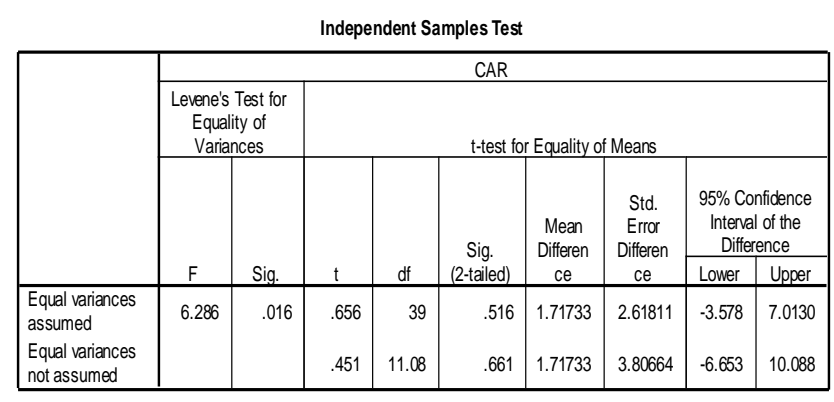

Sumber: Sumber: Hasil Output SPSS (2018)

Berdasarkan tabel dapat diuraikan hasil analisis pengujian hipotesa, terlihat uji homogen (F) untuk variabel CAR dengan Equal Variance Asuumed (diasumsikan kedua varans sama) adalah 6, 286 dengan probabilitas 0,016 . Oleh karena nilai probabilitas lebih besar dari 0, 05, maka Ho diterima atau dinyatakan bahwa kedua varians sama. Nilai $t$ hitung untuk variabel CAR dengan Equal Variance Asuumed adalah 0, 451 dengan signifikansi 0, 661, karena nilai signifikansi $0,661>0,05$,maka Ho diterima dan Ha ditolak, maka dapat dikatakan bahwa variabel CAR bank umum konvensional dan bank 
umum syariah tidak mempunyai perbedaan yang signifikan.

\section{Uji Man-Whitney}

Setelah melakukan pengujian normalitas maka didapatkan hasil data yang terdistribusi normal dan tidak terdistribusi dengan normal. Pada data yang tidak terdistribusi dengan normal dilakukan uji ManWhitney untuk mengetahui perbandingan terhadap dua sampel yang tidak berhubungan apakah terdapat perbedaan atau tidak. Dalam menentukan varians identik dapat ditentukan dengan menggunakan hipotesis berikut:

Ho: Varians tingkat kesehatan Bank umum konvensional dan bank umum syariah dengan menggunakan metode RGEC pada tahun 20142017 adalah sama.

Ha: Varians tingkat kesehatan Bank umum konvensional dan bank umum syariah dengan menggunakan metode RGEC pada tahun 20142017 adalah berbeda.

Pengambilan keputusan:

1. Jika capital $>0,05$ maka Ho tidak dapat ditolak jadi varians sama.

2. Jika capital<0, 05 maka Ho ditolak jadi varians berbeda.

\section{Analisis Pengujian Hipotesis Good Corporate Governance (GCG)}

$\mathrm{H}_{6}$ : Ada perbedaan tingkat kesehatan Bank Umum Konvensional dengan bank umum syariah jika dilihat dari faktor Good Corporate Governance 2014-2017.

Tabel 4.14

Ranks GCG

Ranks

\begin{tabular}{|ll|r|r|r|}
\hline & Jenis Bank & \multicolumn{1}{|c|}{$\mathrm{N}$} & Mean Rank & Sum of Ranks \\
\hline GCG & Konvensional & 30 & 20.83 & 625.00 \\
& Syariah & 11 & 21.45 & 236.00 \\
& Total & 41 & & \\
\hline
\end{tabular}

Sumber: Hasil Output SPSS (2018)

Rata-rata bank umum konvensional adalah sebesar 2083 sedangkan untuk rata-rata bank umum syariah sebesar 21, 45. Dari pengujian secara matematis dapat dilihat dari jumlah rata-rata bahwa variabel GCG antara bank umum konvensional dan bank umum syariah memiliki rata-rata (Mean) berbeda. Dari tabel diatas dapat dilihat bahwa nilai GCG pada bank umum konvensional lebih besar dibandingkan dengan bank umum syariah, hal ini dapat disimpulkan bahwa bank umum konvensional lebih memiliki tata kelola perusahaan yang lebih baik. Dengan adanya perbedaan pengujian secara matematis maka diperlukan pengujian secara statistik. Perhitungan statistik sebagai berikut:

Tabel 4.15

Uji Man- Whitney GCG

\begin{tabular}{|c|c|}
\hline & GCG \\
\hline Mann-Whitney $U$ & 160.000 \\
\hline Wilcoxon W & 625.000 \\
\hline Z & -.163 \\
\hline Asymp. Sig. (2-tailed) & .871 \\
\hline $\begin{array}{l}\text { Exact Sig. [2*(1-tailed } \\
\text { Sig.)] }\end{array}$ & $.896^{a}$ \\
\hline
\end{tabular}

Sumber: Hasil Output SPSS (2018)

Dari tabel diatas, terlihat nilai U GCG adalah 160, 000 dengan prpbabilitas 0,871 . Oleh karena probabilitas 0, $871>0,05$, maka Ho diterima dan Ha ditolak, maka dapat dikatakan bahwa variabel GCG bank umum konvensional dan bank umum syariah tidak mempunyai perbedaan yang signifikan.

\section{Pembahasan}

Setelah melakukan uji hipotesis menggunakan uji independen Sample t-Test dan uji Mann-Whitney dengan tingkat signifikansi 5\% menunjukkan bahwa ada tiga variabel yang tidak ada perbedaan antara bank umum konvensional dan bank umum syariah dalam tingkat kesehatannya. Variabel yang tidak ada perbedaan antara lain Good Corporate Governance (GCG), Net Interest Margin (NIM), dan Capital Adequacy Ratio (CAR). Berikut adalah tabel hasil output data dengan menggunakan Uji Independen Sample t-Test dan Uji Mann-Whitney: 
Tabel 4.28

Rekapitulasi Hasil Uji Independen Sample t-Test dan Uji Mann-Whitney

\begin{tabular}{|l|c|}
\hline \multicolumn{1}{|c|}{ Variabel } & Hasil Interpretasi \\
\hline Non Performing Loan $(\mathrm{NPL})$ & Ada perbedaan \\
\hline Loan to Deposit Ratio (LDR) & Ada perbedaan \\
\hline Good Corporate Governance (GCG) & Tidak ada perbedaan \\
\hline Return on Asset (ROA) & Ada perbedaan \\
\hline Net Interest Margin (NIM) & Tidak ada perbedaan \\
\hline Capital Adequacy Ratio $(\mathrm{CAR})$ & Tidak ada perbedaan \\
\hline
\end{tabular}

Sumber: Data diolah (2018)

Berdasarkan hasil analisis, rasio Risk Profile yang diukur menggunakan Non Performing Loan (NPL) ada terdapat perbedaan antara bank umum konvensional dan bank umum syariah. Dimana, bank umum syariah memiliki kemampuan manajemen bank yang baik dalam mengelola kredit bermasalah dari keseluruhan kredit. Dapat diartikan bank umum syariah dapat mengontrol tingkat kredit dengan baik dan kredit yang diberikan terus meningkat. Hal ini juga dapat menggambarkan profitabilitas yang bagus terhadap pengembalian dana pihak ketiga. Analisis ini sejalan dengan penelitian yang dilakukan oleh (Daniswara \& Sumarta, 2016), sehingga dapat disimpulkan sebagai berikut:

\section{$\mathrm{H}_{1}$ : Terdapat Perbedaan Signifkan Non Performing Loan (NPL) Antara Bank umum konvensional dan bank umum syariah $\left(\mathrm{H}_{2}\right.$ diterima $)$}

Hasil analisis, rasio Risk Profile yang diukur menggunakan Loan to Deposit Ratio (LDR) ada terdapat perbedaan antara bank umum konvensional dan bank umum syariah. Dimana, bank umum syariah memiliki kemampuan manajemen bank yang baik dalam mengelola kredit bermasalah dari keseluruhan kredit. Dapat diartikan bank umum syariah dapat mengontrol tingkat kredit dengan baik dan kredit yang diberikan terus meningkat. Hal ini juga dapat menggambarkan profitabilitas yang bagus terhadap pengembalian dana pihak ketiga. Analisis ini sejalan dengan penelitian yang dilakukan oleh (Daniswara \& Sumarta, 2016), sehingga dapat disimpulkan sebagai berikut:
$\mathrm{H}_{2}$ : Terdapat Perbedaan Signifkan Loan to Deposit Ratio (LDR) Antara Bank umum konvensional dan bank umum syariah $\left(\mathrm{H}_{2}\right.$ diterima)

Hasil analisis Good Corporate Governance (GCG) yang mengukur dengan cara melihat peringkat komposit bank menunjukkan tidak terdapat perbedaan yang signifikan antara bank umum konvensional dan bank umum syariah. Dalam bank umum konvensional tidak menerapkan prinsip tersebut sedangkan bank umum syariah menerapkan prinsip tersebut dan juga menerapkan prinsip kekeluargaan, keadilan, kemashlatan, dan keseimbangan, hal ini belum diperhatikan oleh bank umum konvensional. Analisis ini sejalan dengan penelitian yang dilakukan oleh (Fitriana et al 2015), sehingga dapat disimpulkan sebagai berikut:

\section{H3: Tidak Terdapat Perbedaan Signifkan Good Corporate Governance Antara Bank umum konvensional dan bank umum syariah $\left(\mathrm{H}_{2}\right.$ ditolak)}

Rentabilitas sebagai salah satu penilaiaan tingkat kesehatan bank yang menggunakan rasio Net Interest Margin (NIM) menunjukkan bahwa tidak terdapat perbedaan antara bank umum konvensional dan bank umum syariah hal ini terlihat dari indikator manajerial bank yang mengindikasikan kemampuan manajemen dalam mengelola asetnya untuk memperoleh laba. Analisis ini sejalan dengan penelitian yang dilakukan oleh (Sugari et al 2015), sehingga dapat disimpulkan sebagai berikut:

\section{$\mathrm{H}_{4}$ : Tidak Terdapat Perbedaan Signifkan Antara Bank umum konvensional dan bank umum syariah $\left(\mathrm{H}_{2}\right.$ ditolak)}

Rentabilitas menggunakan rasio Return on Assets (ROA) menunjukkan bahwa terdapat perbedaan antara bank umum konvensional dan bank umum syariah hal ini terlihat dari indikator manajerial bank yang mengindikasikan kemampuan manajemen dalam mengelola asetnya untuk memperoleh laba. Semakin besar Return on Asset (ROA), semakin besar pula tingkat laba yang dicapai bank tersebut. Bank umum 
konvensional menunjukkan transaksi yang lebih luas daripada bank umum syariah sehingga mempunyai tingkat profitabilitas lebih baik dibandingkan bank syariah yang memilkik batasan dalam transaksi. Analisis ini sejalan dengan penelitian yang dilakukan oleh (Daniswara \& Sumarta, 2016), sehingga dapat disimpulkan sebagai berikut:

\section{H$_{5}$ : Tidak Terdapat Perbedaan Signifkan Antara Bank umum konvensional dan bank umum syariah $\left(\mathrm{H}_{2}\right.$ diterima)}

Permodalan diukur dengan menggunakan rasio Capital Adequacy Ratio (CAR). Capital Adequacy Ratio (CAR) antara Bank umum konvensional dan bank umum syariah tidak menunjukkan adanya perbedaan siginifikan antara kedua bank tersebut. Hal ini menunjukkan kedua bank tersebut mampu mengelola modal dan meminimalisir terjadinya risiko kegagalan kredit yang terjadi, sehingga semakin tinggi angka rasio maka menunjukkan bahwa tersebut semakin sehat begitu pula sebaliknya. Hal ini sejalan dengan penelitian yang dilakukan oleh (Anggraini 2015), sehingga dapat disimpulkan sebagai berikut:

\section{$\mathrm{H}_{6}$ : Tidak Terdapat Perbedaan Signifkan Capital Antara Bank umum konvensional dan bank umum syariah $\left(\mathrm{H}_{2}\right.$ ditolak $)$.}

\section{Kesimpulan, Keterbatasan Dan Saran \\ Kesimpulan}

Berdasarkan hasil penelitian mengenai perbandingan tingkat kesehatan bank umum konvensional dan bank umum syariah menggunakan metode RGEC, maka dapat diambil kesimpulan sebagai berikut:

1. Dalam pengujian menggunakan SPSS, tingkat kesehatan bank diukur dengan menggunakan enam variabel antara lain NPL, LDR GCG, ROA, NIM, dan, CAR. Hasil dari pengujian secara statistika didapatkan bahwa ada beda antara beberapa variabel penilai tingkat kesehatan bank umum konvensional dan bank umum syariah, variabel tersebut antara lain NPL, LDR dan ROA.

2. Dalam pengujian menggunakan SPSS, tingkat kesehatan bank diukur dengan menggunakan enam variabel antara lain NPL, LDR GCG, ROA, NIM, dan, CAR. Hasil dari pengujian secara statistika didapatkan bahwa tidak ada beda antara beberapa variabel penilai tingkat kesehatan bank umum konvensional dan bank umum syariah, variabel tersebut antara lain GCG, NIM, dan CAR. Setelah melakukan perhitungan dalam menentukan tingkat kesehatan dengan metode RGEC menggunakan enam variabel tingkat dapat disimpulkan bahwa secara umum selama empat tahun pada periode 2014-2017 bank umum konvensional dan bank umum syariah dalam kondisi yang baik.

3. Penentuan kesehatan bank dengan menggunakan metode RGEC lebih menekan akan pentingnya kualitas manajemen. Manajemen yang berkualitas tentunya akan mengangkat faktor pendapatan dan juga faktor permodalan secara langsung maupun tidak langsung.

\section{Keterbatasan}

Terdapat keterbatasan dan kelemahan dalam penelitian ini. Oleh karena itu, keterbatasan dan kelemahan dalam penelitian ini perlu diperhatikan dalam penelitian selanjutnya, adapun keterbatasan dan kelemahan dalam penelitian ini adalah sebagai berikut:

1 Data keuangan perbankan yang dijadikan sebagai indicator penilaian tingkat kesehatan bank tidak sepenuhnya tercantum dalam laporan keuangan yang dipublikasikan bank, sehingga ada beberapa Indikator yang belum dapat dinilai antara lain faktor risiko pasar, risiko operasional, risiko hukum, risiko stratejik, risiko kepatuhan, dan risiko reputasi.

2 Dalam faktor Risk Profile tidak semua indikator dinilai hanya risiko kredit dan risiko likuiditas saja yang dinila karena adanya keterbatasan informasi yang didapat pada bank yang diteliti.

\section{Saran}

Berdasarkan simpulan, saran dari penelitian ini adalah agar masyarakat sebagai konsumen lebih teliti dalam menginvestasikan uangnya di dalam sebuah bank, konsumen sebagai investor perlu mempertimbangkan tingkat kesehatan bank baik bank umum konvensional dan bank umum syariah. Penelitian ini juga diharapkan perlu meneliti bankbank yang tidak mencantumkan peringkat profil risikonya. Penelitian selanjutnya diharapkan dapat menggunakan proksi yang beragam untuk menilai 
masing-masing faktor RGEC, terutama pada penilaian profil risiko diharapkan dapat dianalisis menggunakan proksi yang sesuai, tidak hanya menggunakan peringkat hasil penilaian bank yang sudah tercantum di laporan keuangan tahunan. Selain itu diharapkan pada penelitian selanjutnya untuk dapat mengembangkan analisis tingkat kesehatan bank.

\section{Daftar Pustaka}

Anggraini Mentari, Moch. Dzulkiron, dan Muhammad Saifi, (2015). Analisis Kinerja Keuangan Bank Konvensional dan Bank Syariah dengan Menggunakan Pendekatan RGEC (Studi Pada PT.BRI, Tbk Dan PT.BRI Syariah Periode 2011-2013). Jurnal Administrasi Bisnis (JAB) Vol, 27(1).

Arv,(2017).http://mediaindonesia.com/read/detail/966 48-bank-banten-lepas-dari pengawasan-khusus diakses 16 Maret 2017

Agustiyanti,(2018).https://www.cnnindonesia.com/eko nomi/20180302083629-78 279866/bankmuamalat-rawan-kritis-meski-cuma-masukangin diakses 02 maret 2018

Bank Indoneisia. Peraturan Bank Indonesia No:6/23/DPNP/2004 tentang Penilaian Tingkat Kesehatan Bank Umum

Bank Indoneisia. Peraturan Bank Indonesia No:13/1/PBI/2011 tentang Penilaian Tingkat Kesehatan Bank Umum

Bank Indoneisia. Peraturan Bank Indonesia No:8/4/PBI/2006 tentang Pelaksanaan good corporate governance

Bank Indoneisia. Peraturan Bank Indonesia No:15/15/DPNP/2013 tentang Pelaksanaan good corporate governance

Daniswara Fitria \& Sumarta Harsa Nurmandi (2016). Analisis Perbandingan Kinerja Keuangan Berdasarkan Risk Profile, Good Corporate Governance, Earnings, dan Capital (RGEC) pada Bank Umum Konvensional dan Bank Umum Syariah Periode 2011-2014. Gema, ISSN:2344-2360.

Deehani, Hasan Mounir, dan Mohammad T.Al(2015). Performance Of Islamic Banks And Conventional Banks Before And During Economic Downturn. Investment Management and Financial Innovations, Vol.12(2).

Fitriana Nur, Ahmad Rosyid, dan Agus Fakhrina.
(2015). Analisis Perbandingan Tingkat Kesehatan Bank Syariah Dan Konvensional Dengan Menggunakan Metode Rgec ( Risk Profile, Good Corporate Governance, Earnings, Dan Capital ). Fakultas Ekonomi Dan Bisnis, 17(2), 1-12.

Ghozali, (2013). Aplkasi Analisis Multivariate dengan Program SPSS. Semarang: Badan Penerbit Universitas Diponegoro.

Gustina. (2015). Tinjauan Kesehatan Bank Melalui Metode Risk Based Bank Rating . Polibisnis, 7(1), 1-11.

Gujarati, (2012). Dasar-Dasar Ekonometrika. Jakarta: Salemba Empat

Husein Arif Rachman \& Fatin Fadhilah Hasib, (2016). Tingkat Kesehatan Bank: Analisa Perbandingan Pendekatan CAMELS dan RGEC (studi pada bank umum syariah tahun periode 2012-2014. Jurnal Ekonmi Syariah Teori Dan Terapan, 3, 15

Jayanti Chindy Dwi \& Isharijadi, (2017). Analisis Rgec untuk Menilai Tingkat Kesehatan Bank Pada Bank Rakyat Indonesia (Studi Kasus Pada Bursa Efek Indonesia). Forum Ilmiah Pendidikan Akuntansi, 5 no.1(September), 3544.

Kasmir,(2007). Dasar-Dasar Perbankan, Jakarta: Raja Grafindo Persada

Kasmir,(2008). Dasar-Dasar Perbankan, Jakarta: Raja Grafindo Persada

Khalil Muhammad \& Raida Fuadi. (2016). Analisis Penggunaan Metode Risk Profile, Good Corporate Governance, Earning, And Capital ( Rgec ) Dalam Mengukur Kesehatan Bank Pada Bank Umum Syariah Di Indonesia Periode 2012-2014 Keywords : RGEC Method , Risk Base Bank Rating. Jurnal Ilmiah Mahasiswa Ekonomi Akuntansi (JIMEKA), l(1), 20-35.

Komariah Eus, (2016). Tingkat Kesehatan Bank Umum Syariah di Indonesia dari Aspek. Jurnal Online Insan Akuntan, Vol.1,No.2 EISSN:2528-0163

Lasta Heidy Arrvida, Zainul Arifin, dan Nila Firdausi Nuzula, (2014). Analisis Tingkat Kesehatan Bank dengan Menggunakan Pendekatan RGEC (Risk Profile, Good Corporate Governance, Earnings, Capital) (Studi pada PT 
Bank Rakyat Indonesia Periode 2011-2013). Jurnal Administrasi Bisnis, 13(2), 1-8. https://doi.org/10.1017/CBO9781107415324.0 04

Maradita Aldira, (2014). Karakteristik Good Corporate Governance pada Bank Syariah dan Bank Konvensional. Yuridika; Vol.29 No.2

Muctar Bustari, Rose Rahmidini, dan Menik Kurnia (2016). Bank dan Lembaga Keuangan Lain. Jakarta: kencana

Sattar.(2017). Ekonomi Internasional. Yogyakarta: Deepublish

Sekaran Uma \& Roger Bougie, (2013). Research Methods for Business. A Skill Building Approah $6^{\text {th }}$ Edition. New York: John Willey $\&$ Sons Ltd.

Sekaran Uma \& Roger Bougie, (2017). Research Methods for Business. New York: John Willey $\&$ Sons Ltd.

Sugiyono, (2012). Metode Penelitian Kuantitatif dan Kualitatif. Bandung: CV Alfabeta

Sugari Bella Puspita, Bambang Sunarko, dan Yayat Giyatno, (2015). Syariah dan Konvensional dengan Menggunakan Metode Rgec ( Risk Profile , Good Corporate Governance , Earnings, Dan Capital ). Jurnal Administrasi Bisnis (JAB).Risk Profile. Jurnal Online Insan Akuntan, 1(2), 239-260.

Peraturan Otoritas Jasa Keuangan No.8/POJK.03/2014 tentang Penilaian Tingkat Kesehatan Bank Umum Syariah dan Unit Usaha Syariah

Peraturan Otoritas Jasa Keuangan No.4/POJK.03/2016 tentang Penilaian Tingkat Kesehatan Bank Umum

Peraturan Otoritas Jasa Keuangan No.55/POJK.03/2016 tentang Penerapan Tata Kelola

Pujiati Lllik \& Iis Wahyuningsih, (2016). Perbedaan Manajemen Laba pada Bank Syariah dan Bank Konvensional yang Terdaftar di Otoritas Jasa Keuangan. Akademika; Vol.14 No.2

Putri Ratna Lutfiani \& Bambang Suryono, (2017). Analisis Tingkat Kesehatan Bank (Pendekatan RGEC) pada Bank Rakyat Indonesia 20132015. Jurnal Ilmu dan Riset Akuntansi. Vol 6 No 8, ISSN:2460-0585

Prastyananta Fungki, Muhammad Saifi, dan Maria Goretti, (2016). Analisis Penggunaan Metode
RGEC (Risk Profile, Good Corporate Governance, Earning, dan Capital) untuk Mengetahui Tingkat Kesehatan Bank (Studi pada Bank Umum yang Terdaftar di BEI Periode 2012-2014). Jurnal Administrasi Bisnis (JAB), 35(2), 68-76. Retrieved from administrasibisnis.studentjournal.ub.ac.id

Sunarti. (2011). sistem manajemen perbankan indonesia.

Yusmad Muammar Arafat, (2018). Aspek Hukum Perbankan Syariah dari Teori ke Praktik, Yogyakarta: Deepublish 